\title{
Effects of Dietary Protein or Amino Acids in the Perfusion Medium on Amino Acid Metabolism in Perfused Adult Rat Liver
}

\author{
Yoshiaki FujITA, ${ }^{1}$ Takashi YAMAMOTo, ${ }^{2}$ Toru RIKIMARU, ${ }^{1}$ \\ Hidemichi EBISAWA, ${ }^{2}$ and Goro INOUE ${ }^{2}$ \\ ${ }^{1}$ Nutrition Research Laboratory, Tokyo Metropolitan Institute of Gerontology, \\ 35-2 Sakae-cho, Itabashi-ku, Tokyo 173, Japan \\ ${ }^{2}$ Department of Nutrition, School of Medicine, Tokushima University, \\ 3 Kuramoto-cho, Tokushima 770, Japan
}

(Received October 8, 1980)

\begin{abstract}
Summary To elucidate the response of amino acid metabolism in the liver to dietary protein and plasma amino acids, the livers of adult rats fed on diet containing 10\% (control) or 3\% (low-protein) egg protein for 3 weeks were perfused for $120 \mathrm{~min}$ with amino acid-free medium in Experiment 1 or medium containing an amino acid mixture simulating that in plasma in Experiment 2. During perfusion about $40 \%$ of the free amino acids were lost from the liver in Exp. 1, and about 30\% in Exp. 2. During this period, in Exp. 1 the releases of free amino acids and urea into the medium were $140 \mu \mathrm{mol}$ and $2.52 \mathrm{mg}$, respectively, in the control group and $207 \mu \mathrm{mol}$ and $1.10 \mathrm{mg}$, respectively, in the low-protein group. Thus release was greater than decrease in free amino acids in the liver. Essential amino acids, particularly lysine and branched chain amino acids, were released preferentially. The results suggest that the amount of breakdown of liver protein in the two groups was similar, but that the nitrogen was mainly released as free amino acids in the low-protein group, and as urea in the control group. On the contrary, in Exp. 2 the amount of nitrogen released from the liver was comparable to the decrease in amino acids in the liver, and the releases of urea were also less, being $1.83 \mathrm{mg}$ in the control group and $0.54 \mathrm{mg}$ in low-protein group. The results show that amino acid metabolism in the liver is greatly affected by the nutritional state of the animal and the amino acid content of the perfusion fluid.
\end{abstract}

Key Words liver pefusion, amino acid balance in liver, adult rats, egg protein, urea synthesis

Previously we suggested (1) that plasma free amino acids do not directly reflect the amino acid composition or level of ingested protein, but indirectly reflect the

1 藤田美明, ${ }^{2}$ 山本孝史, ${ }^{1}$ 力丸 徹, ${ }^{2}$ 海老沢秀道, ${ }^{2}$ 井上五郎 
overall picture of amino acid metabolism in various tissues in response to the quality and quantity of ingested proteins. Thus, to understand the nutritional significance of plasma free amino acids, it is very important to elucidate the amino acid metabolisms in different organs and their interrelations. Amino acid metabolism in whole organs has mainly been studied by the tissue perfusion method with isolated organs and blood $(2,3)$ or by the artery-venous difference method (4). Ishikawa's group (5-7) have obtained much useful information on amino acid metabolism in various tissues of starving and fed rats using the latter method. However, it is difficult to determine quantitative changes of metabolism by this method. There are many reports extant on the investigation of amino acid metaoblism in perfused rat liver (8-11), however, at the end of the day, none of the reports clarified the relations to dietary protein at all. Recently, Oyanagi et al. (12) and Krone et al. (13) demonstrated that perfluoro chemicals could be used as oxygen carriers instead of red blood cells. Therefore, in this study on the nutritional signification of plasma free amino acids we used the perfusion method with perfluorocarbon for oxygen transport and examined the responses of amino acid metabolism in adult rat liver to dietary protein and to plasma free amino acids.

\section{EXPERIMENTAL}

Animals and diets. Male Sprague-Dawley strain rats weighing about $250 \mathrm{~g}$ were fed on commercial stock diet until they weighed about $300 \mathrm{~g}$, and were then divided into 6 groups of 6 to 8 rats each and housed individually in an air-conditioned room. They were given the experimental diets shown in Table 1 ad libitum for 3 weeks.

Three control groups were given diet containing $10 \%$ lyophilized whole egg protein and 3 groups were given diet containing 3\% egg protein as low-protein diet. Body weight and food consumption were recorded daily.

Perfusion. At the end of 3 weeks, the animals were starved for exactly $12 \mathrm{hr}$ and one group on $10 \%$ protein and one on $3 \%$ protein were killed to measure the levels of free amino acids in the liver. For the liver perfusion, the other 2.groups on each diet were treated according to the procedure of Hems et al.(14) and the liver was perfused in situ for 120 min with a Mortimore model apparatus(15). The compositions of the perfusion media used are shown in Table 2. In Experiment 1, the liver was perfused with amino acid-free medium, while in Experiment 2 it was perfused with medium containing free amino acids simulating those in the plasma of adult rats on $10 \%$ egg protein diet. The other components of the perfusate were $2.5 \%$ human albumin, to obtain a suitable colloidal osmotic pressure, $10 \%$ perfluorocarbon (FC-43 from the Green Cross Corporation) as a carrier of $\mathrm{O}_{2}$ and $\mathrm{CO}_{2}$ and $100 \mathrm{mg}$ per $100 \mathrm{ml}$ of glucose. Seventy milliliters of medium were put into the reservoir and saturated with oxygen from an oxygenator. The oxygen-saturated medium was pumped up through the filter and bubble drain, to the liver via the portal vein at a flow rate of $10 \mathrm{ml}$ per $\mathrm{min}(1 \mathrm{ml} / \mathrm{g}$ liver per $\mathrm{min})$. The hepatic artery 
Table 1. Compositions of experimental diets.

\begin{tabular}{|c|c|c|}
\hline Ingredients & $\begin{array}{c}10 \% \text { egg } \\
\text { protein } \\
\text { diet }\end{array}$ & $\begin{array}{c}3 \% \text { egg } \\
\text { protein } \\
\text { diet }\end{array}$ \\
\hline & \multicolumn{2}{|c|}{$(\mathrm{g} / 100 \mathrm{~g}$ of diet $)$} \\
\hline Extracted whole egg protein ${ }^{a}$ & 10.67 & 3.20 \\
\hline Sucrose & 25.36 & 27.85 \\
\hline$\alpha$-Starch & 50.72 & 55.70 \\
\hline Vitamin mixture $^{\mathrm{b}}$ & \multicolumn{2}{|c|}{1.0} \\
\hline Choline chloride & \multicolumn{2}{|c|}{0.2} \\
\hline Chocola $\mathrm{A}^{\mathrm{c}}$ & \multicolumn{2}{|c|}{0.05} \\
\hline Salt mixture ${ }^{b}$ & \multicolumn{2}{|c|}{5.0} \\
\hline Cellulose powder & \multicolumn{2}{|c|}{2.0} \\
\hline Corn oil & \multicolumn{2}{|c|}{5.0} \\
\hline
\end{tabular}

Table 2. Composition of perfusion medium.

\begin{tabular}{|c|c|c|c|c|c|c|c|}
\hline \multicolumn{8}{|c|}{ Amino acid composition of medium $(\mu \mathrm{mol} / \mathrm{liter})^{\mathrm{a}}$} \\
\hline Thr & 215 & Tyr & 54 & Asp & 29 & EAA & 1,250 \\
\hline Cys & 68 & Phe & 68 & Ser & 410 & NEAA & 1,411 \\
\hline Val & 150 & Lys & 280 & Glu & 141 & Total & 2,661 \\
\hline Met & 12 & Trp & 54 & Gly & 364 & $\mathrm{E} / \mathrm{N}$ & 0.89 \\
\hline Ile & 87 & His & 45 & Ala & 327 & & \\
\hline Leu & 120 & Arg & 97 & Pro & 140 & & \\
\hline \multicolumn{8}{|c|}{ Krebs-Ringer bicarbonate buffer ( $\mathrm{pH}$ 7.4) } \\
\hline \multicolumn{3}{|c|}{ Albumin ${ }^{b}$} & \multicolumn{5}{|c|}{$2.5 \mathrm{~g} / 100 \mathrm{ml}$} \\
\hline \multicolumn{3}{|c|}{ Glucose } & \multicolumn{5}{|c|}{$100 \mathrm{mg} / 100 \mathrm{ml}$} \\
\hline \multicolumn{3}{|c|}{ Fluorocarbon ${ }^{c}$} & \multicolumn{5}{|c|}{$10 \mathrm{~g} / 100 \mathrm{ml}$} \\
\hline
\end{tabular}

a The composition simulated that in the plasma of rats on $10 \%$ egg protein diet.

b Human serum albumin, Fraction V, purchased from Sigma Chemical Co., St. Louis,

Mo. ${ }^{c}$ FC-43 as $\mathrm{O}_{2}-\mathrm{CO}_{2}$ carrier for perfusion, obtained from Green Cross Corp., Osaka, Japan.

was ligated and the medium issuing from the hepatic vein was reintroduced into the reservoir. The physiological temperature and suitable humidity were maintained for the apparatus, and adequate perfusion was judged by macroscopic observation and by measuring the $\mathrm{pH}$, bile production, etc.

Determinations. After perfusion for $120 \mathrm{~min}$, the liver was removed rapidly and weighed and samples were taken for amino acid analysis. The free amino acids and 
urea released from liver into medium were measured by the method of Stein and Moore(16) with a slight modification(17) and the indophenol method(18), respectively. The free amino acids were analyzed with an automatic amino acid analyzer (Yanaco Model LC-5S). Still, the data expressed as Glu in the tables consist of only glutamic acid.

\section{RESULTS}

\section{Weight gain and food consumption}

Results on weight gain and food consumption are shown in Table 3. In Experiment 1, there was no significant difference in the food consumptions of the control and low-protein groups, and thus the low-protein group consumed about $1 / 3$ as much protein as the control group. Weight gain of the low-protein group was also significantly lower than that of the controls. Food intakes in Experiment 2 were similar to those in Exp. 1 and weight gain of the low-protein group was also significantly lower than that of the controls, although both groups gained more weight than in Exp. 1.

\section{Urea release from the liver into the medium}

The time-course of urea release into the perfusate is shown in Fig. 1. In Exp. 1,

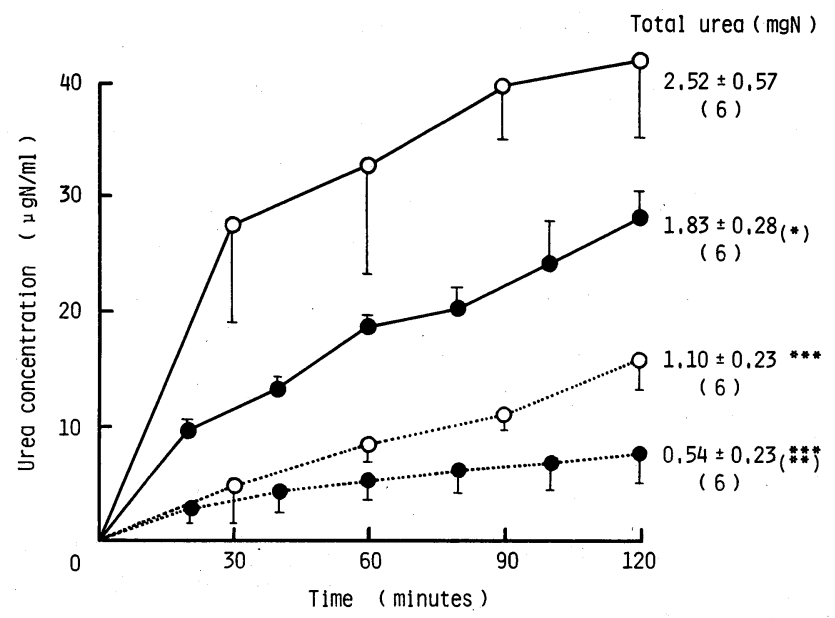

Fig. 1. Time-course of urea released into the medium from perfused rat liver. In Exp. 1, the liver of adult rats fed on $10 \%$ egg protein diet (-O-) or $3 \%$ egg protein diet (---O---) for 3 weeks was perfused with amino acid-free medium for $120 \mathrm{~min}$. In Exp. 2 , the liver of adult rats fed on $10 \%$ egg protein diet (- - ) or $3 \%$ egg protein diet (------) for 3 weeks was perfused in the same way with medium containing amino acids simulating those in normal rat plasma. Figures at the right are mean values \pm SD for total release of urea in $120 \mathrm{~min}$ and figures in parentheses indicate numbers of rats. ${ }^{* * *}$, significantly different from value for $10 \%$ protein group at $p<0.001$. $\left(^{*}\right)$ and $\left({ }^{* *}\right)$, significantly different from the same group in Exp. 1 at $p<0.05$ and $p<0.01$, respectively. 


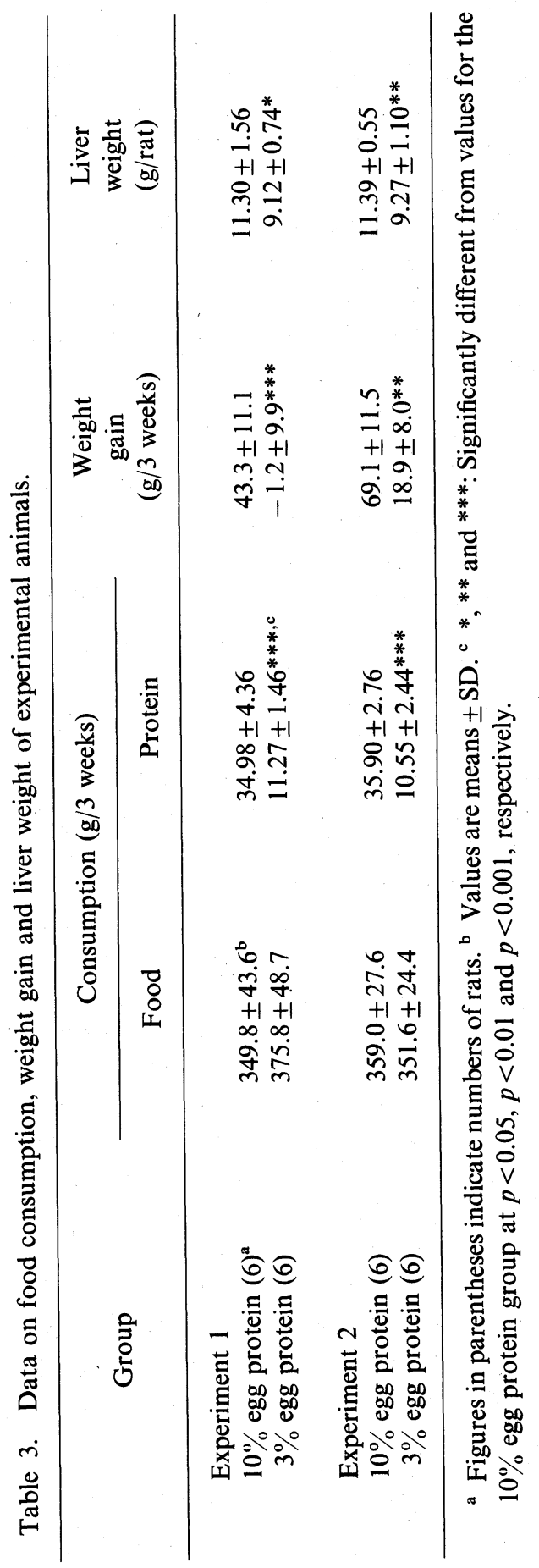

Vol. 27, No. 2, 1981 
the liver of control animals released $67 \%$ of the total urea in the first $30 \mathrm{~min}$ and the rest during the next $90 \mathrm{~min}$; during 2 -hr perfusion $2.52 \pm 0.57 \mathrm{mg}$ of urea $\mathrm{N}$ was released into the medium. On the other hand, the liver of animals on low-protein diet released urea linearly during the perfusion period; total release amounted to $1.10 \pm 0.23 \mathrm{mg}$ of urea $\mathrm{N}$, or about $44 \%$ of the value of controls. These results reflect the dietary protein level. In both groups in Exp. 2, urea was released linealy with time during perfusion; total release of urea $\mathrm{N}$ in $2 \mathrm{hr}$ was $1.83 \pm 0.28 \mathrm{mg}$ in the control group and $0.54 \pm 0.23 \mathrm{mg}$ in the low-protein group. Thus in both Experiments 1 and 2, release of urea in the low-protein group was significantly lower than that in the control group, and the releases by both groups in Exp. 1 were significantly high than those in Exp. 2.

\section{Changes in free amino acids}

The effect of the dietary protein level with or without amino acids in the perfusion medium on free amino acids in the liver and medium before and after perfusion is shown in Tables 4, 5, 6, and 7 .

Changes in total EAA and NEAA in Exp. 1. The total amount of free amino acids in the liver before perfusion was $140.7 \mu \mathrm{mol}$ in the control group and $192.1 \mu \mathrm{mol}$ in the low-protein group. During 2-hr perfusion about $40 \%$ of the free amino acids were lost in both groups and free amino acids appeared in the medium, amounting to $139.4 \pm 35 \mu \mathrm{mol}$ in the control group and $207.1 \pm 37.8 \mu \mathrm{mol}$ in the lowprotein group. Thus the release of free amino acids into the medium was greater than their decrease in the liver, the differences being $85.8 \mu \mathrm{mol}$ in the control group and $132.3 \mu \mathrm{mol}$ in the low-protein group. These amounts must be formed by breakdown of liver protein (Tables 4 and 5).

Changes in total EAA and NEAA in Exp. 2. Perfusion with medium containing free amino acids also resulted in decrease of liver free amino acids, but the decreases in the liver during perfusion were comparable to the increases in the medium, although the pattern of amino acids released differed from that of liver free amino acids. This indicates that perfusion with the medium containing free amino acids resulted in less breakdown of liver protein (Tables 6 and 7).

Net increase in nitrogen in liver perfusion. The amounts of release of amino acids and urea are shown in Fig. 2. In Exp. 1, the sums of the release of amino acids and urea were similar in the 2 groups, being $3,874 \mu \mathrm{gN}$ in the control group and $3,413 \mu \mathrm{gN}$ in the low-protein group. However, in the low-protein group, the nitrogen was mainly released as free amino acids, which can be reutilized, whereas it was mainly released as the end-product urea in the control group. In Exp. 2, release of nitrogen was due to release of urea, there was scarcely any formation of new free amino acids, and thus the value in the control group was more than 3 times that in the low-protein group.

Changes in individual amino acids in Exp. 1. The essential amino acids released most into the medium were lysine and branched chain amino acids. The new formation, as calculated from the decrease in the liver of branched chain amino 


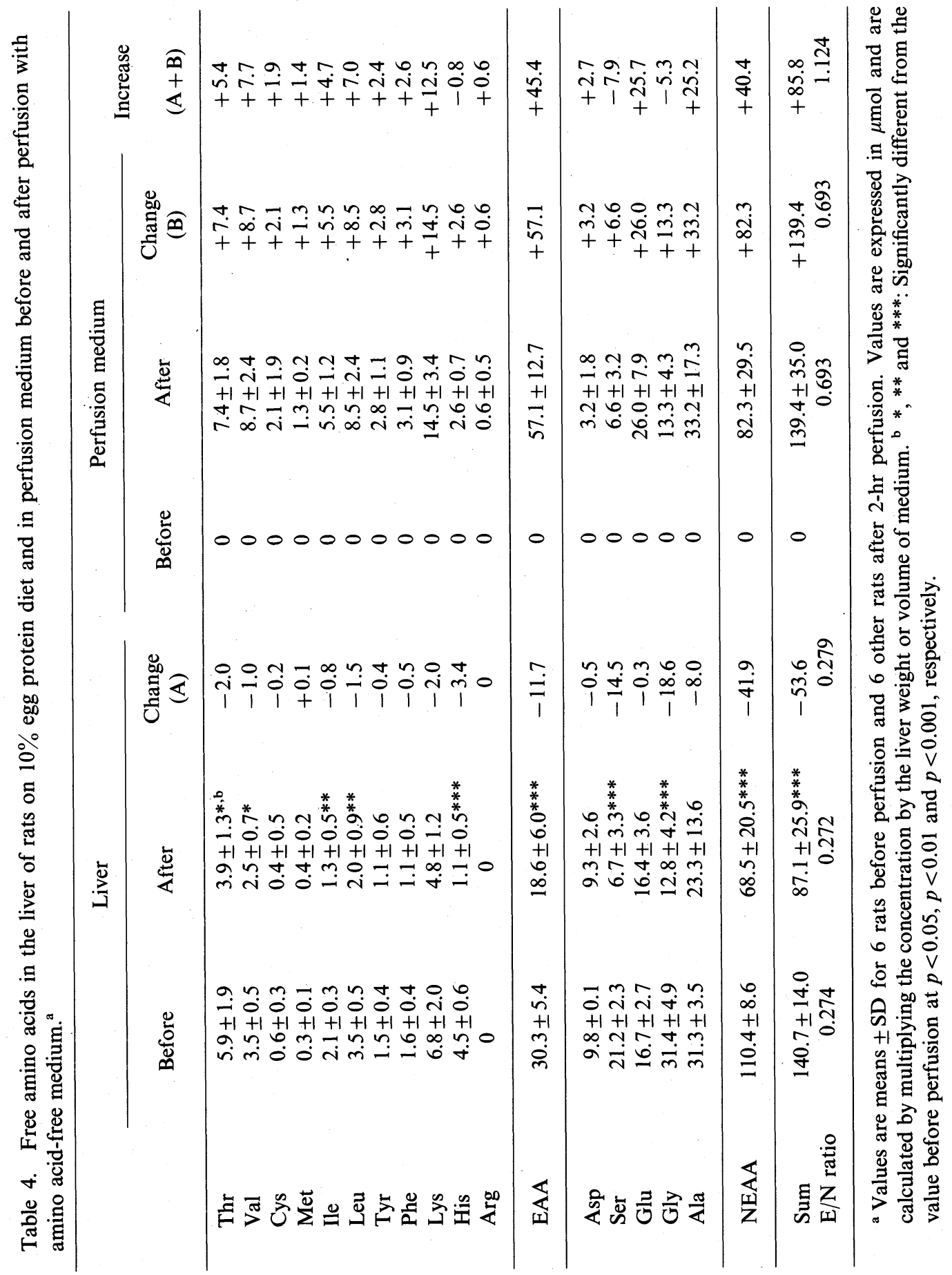

Vol. 27, No. 2, 1981 


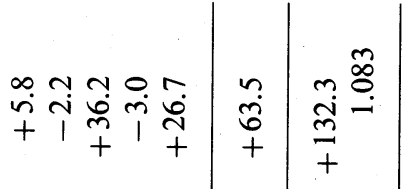

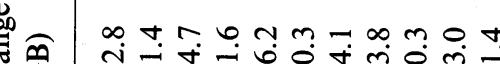
己ี

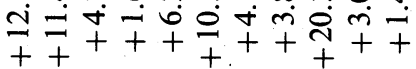
$\stackrel{\circ}{\stackrel{0}{+}}$

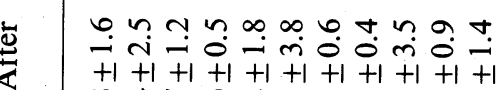
$\infty+0, \cdots=\infty m 0+$

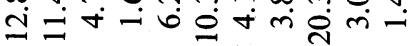

荧

00000000000 胥

$\vec{\infty} \hat{0} \overrightarrow{0}$ ○

$\stackrel{\infty}{1}$

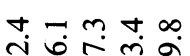

$+1+1+1+1+1$

$\infty \circ m b \infty$

ம்

$\infty \circ \cdots$

+ กิ

$+++$

(1)

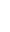

00000

o

\section{莡}

\section{$\stackrel{*}{*}$}

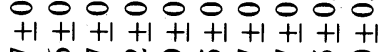

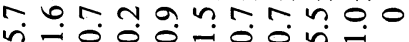

$$
\text { (n) }
$$

人ิ์

$+1+1+1+1+1+1+1+1+1+1$

㐫

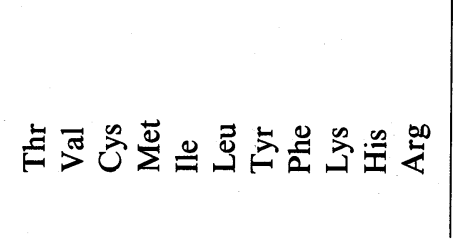

$\stackrel{*}{*}$
$\stackrel{*}{*}$
$\stackrel{+1}{n}$
$\stackrel{n}{\infty}$
-1

$\infty$

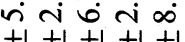

$+1+1+1+1+1$

$\dot{\Delta} \dot{\Delta} \infty$

$-$

त

$\infty \stackrel{0}{\circ} 9 \cong$

i 수

$+1+1+1+1+1$

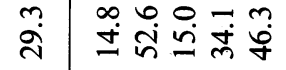

近

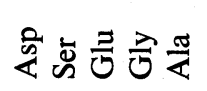

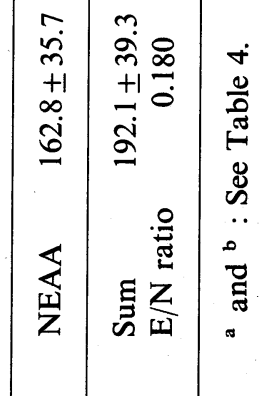

J. Nutr. Sci. Vitaminol. 


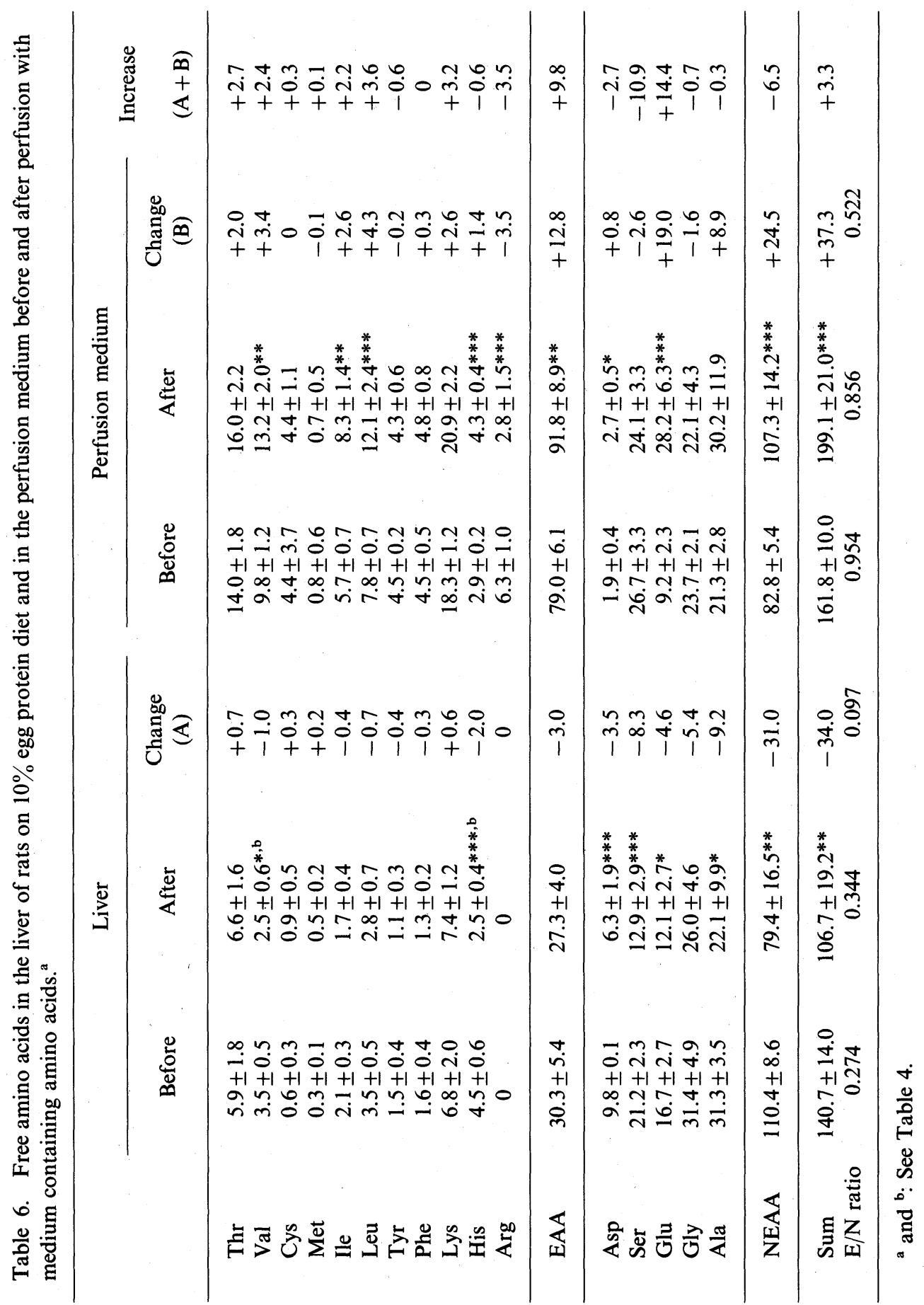

Vol. 27, No. 2, 1981 


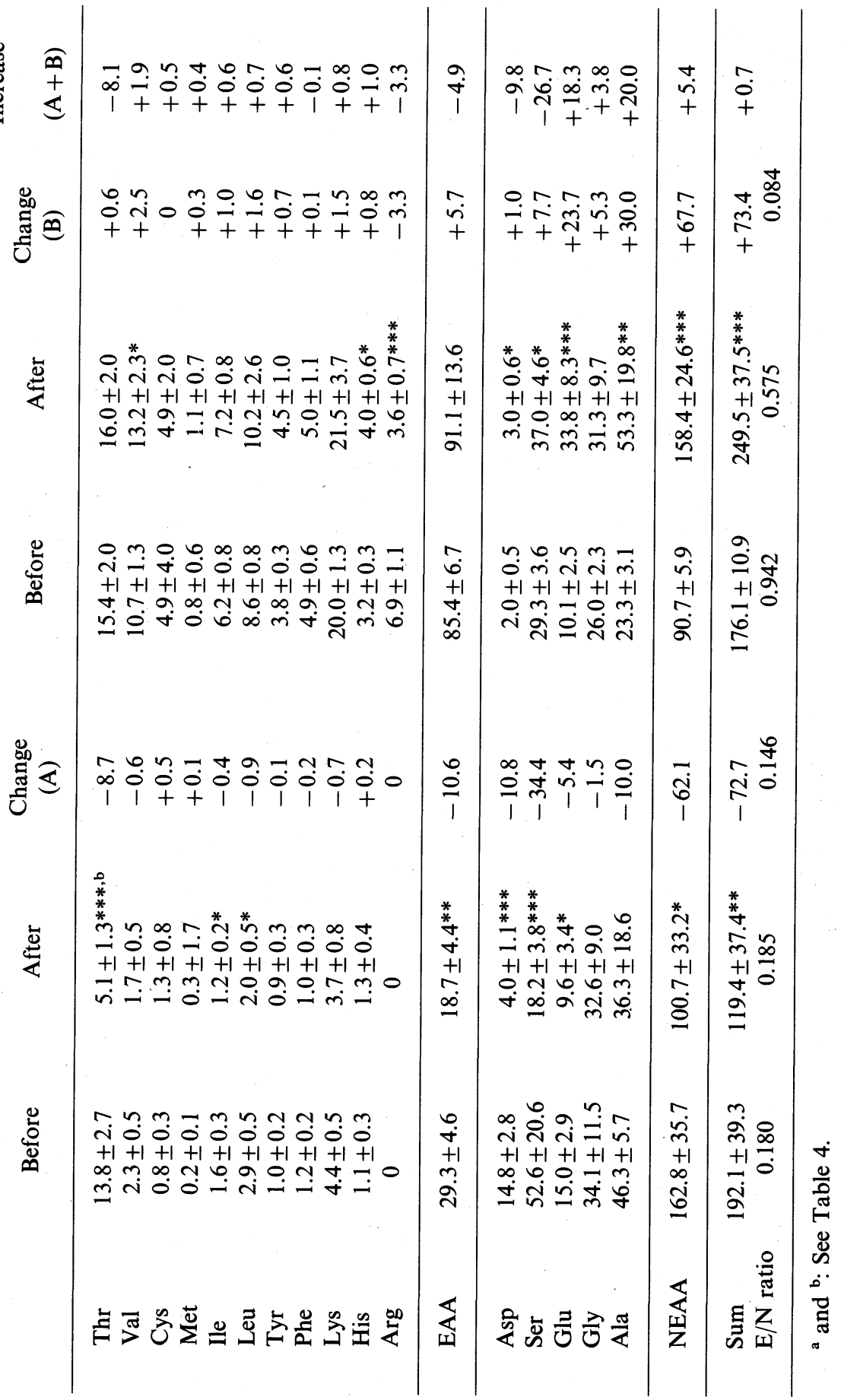




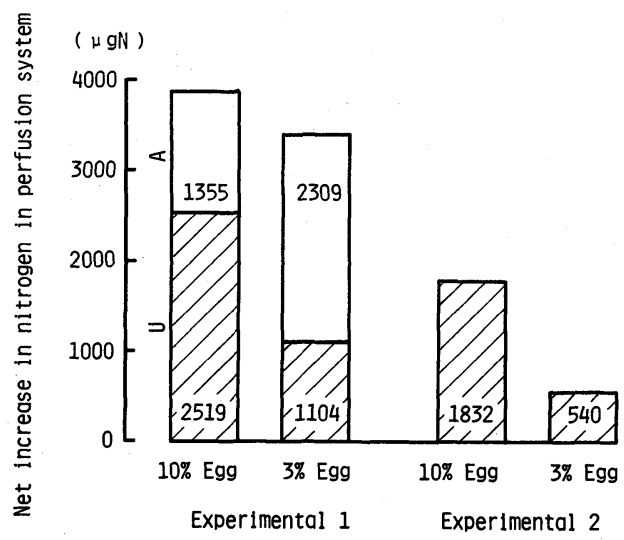

Fig. 2. Effect of dietary protein, with or without amino acids in the perfusion fluid on net increase in free amino acids and urea in the perfusion system in $2 \mathrm{hr}$. Media with and without amino acids (simulating those in normal plasma) were used in Exps. 1 and 2, respectively. Open and shaded bars represent free amino acids and urea, respectively. Net increase of free amino acids was calculated as follows: (change in the medium during perfusion)-(change in the liver during perfusion).

acids, amounted to $19.4 \mu \mathrm{mol}$ in the control group and $25.3 \mu \mathrm{mol}$ in the low-protein group; these amounts were 2-fold and 4-fold the amounts in the liver of the respective groups before perfusion. The main nonessential amino acid released from the liver was alanine $(33.2 \mu \mathrm{mol})$ followed by glutamate and glycine in the control group, and alanine $(43.8 \mu \mathrm{mol})$ followed by glutamate and serine in the low-protein group. These releases, particularly of serine, were greater in the low-protein group than in the control group. However, the levels of many nonessential amino acids decreased in the liver during perfusion, and only the amounts of alanine and glutamate in the medium were greater than those released from the liver and they totalled about $25 \mu \mathrm{mol}$ irrespective of the dietary protein level (Tables 4 and 5).

Changes in individual amino acids in Exp. 2. With regard to essential amino acids, there was scarcely any release into the medium from the liver. The main nonessential amino acid released from the liver was glutamate $(19.0 \mu \mathrm{mol})$ in the control group, and alanine $(30.0 \mu \mathrm{mol})$ followed by glutamate in the low-protein group. These releases were greater in the low-protein group than in the control group, as well as in Exp. 1. On the contrary, serine was scarcely released into the medium and in the low-protein group about $27 \mu$ mol were catabolized in the liver during 2-hr perfusion (Tables 6 and 7).

\section{DISCUSSION}

When the liver of adult rats was perfused with amino acid-free medium for $2 \mathrm{hr}$, there was a decrease of about $40 \%$ in the amount of free amino acids in the liver. At the same times, free amino acids were released into the perfusion medium, and this 
release was greater than the decrease in the liver. As reported previously by us (1) and by Wannemacher and Allison (19), the $\mathrm{E} / \mathrm{N}$ ratio of free amino acids in the liver is lower than that in plasma. In a closed system composed of only medium and liver, it might be supposed that the $\mathrm{E} / \mathrm{N}$ ratio in the medium after perfusion would resemble that in the liver. But we found that the $E / N$ ratio of free amino acids released into the medium more closely resembled that of blood plasma than liver, with preferential release of essential amino acids, and that the liver retained its normal $\mathrm{E} / \mathrm{N}$ ratio. These findings indicate that part of the liver protein was catabolized during perfusion. New formation of free amino acids was about 1.7 -fold greater in the low-protein group than in the control group. On the contrary, the amount of urea released was greater in the control group than in the low-protein group, and consequently total $\mathrm{N}$ release was similar in the 2 groups. These results suggest that the free amino acids formed by breakdown of liver protein are released mainly as the end product, urea, in the control group, and mainly as free amino acids that could be used in other tissues in the low-protein group. Thus these changes in liver-protein metabolism in protein deficiency are understandable.

In Exp. 2, in which the liver was perfused with medium containing amino acids simulating those in plasma, the release of amino acids into the medium was comparable to the decrease of free amino acids in the liver, although the $\mathrm{E} / \mathrm{N}$ ratio in the medium differed from that in the liver. Little new formation of free amino acids caused by liver protein breakdown was observed and the releases of urea by the control and low-protein groups were 70 and $50 \%$ of those in the respective groups in Exp. 1. This result in urea release in Exp. 2 differed from the reports by Hems et al.(20) and Mondon and Mortimore (21) who also perfused with the medium containing amino acids simulating those in plasma. Therefore, decreased urea formation and release in Exp. 2 may depend mainly on decreased protein breakdown in the liver.

With regard to individual amino acids, arginine was not released in appreciable amounts from the liver in either Experiment 1 or 2. Thus plasma arginine in vivo must originate from organs other than the liver(22). The releases and new formations of lysine and branched-chain amino acids were greater than those of other amino acids. Miller (23), Ichihara and Koyama (24) and Mimura et al. (25) demonstrated that branched-chain amino acids are mainly catabolized not in the liver, but in muscle and/or kidney. Therefore, the new formation of these amino acids may reflect the amount of liver protein breakdown. Of the branched-chain amino acids, valine in particular is scarcely metabolized by rat liver transaminase. Accordingly, the apparent amount of liver protein breakdown can be calculated from the amount of new formation of this amino acids. Assuming that liver protein contains $58.0 \mu \mathrm{mol}$ of valine per $100 \mathrm{mg}$ of protein (26), the breakdown of liver proteins in Exp. 1 was calculated to be $13.3 \mathrm{mg} / 2 \mathrm{hr}$ in the control group and $18.4 \mathrm{mg} / 2 \mathrm{hr}$ in the low-protein group. Thus breakdown was greater in the lowprotein group. In Exp. 2, in which the perfusion fluid contained added amino acids, the breakdown was calculated as $4.1 \mathrm{mg} / 2 \mathrm{hr}$ in the control group and $3.3 \mathrm{mg} / 2 \mathrm{hr}$ in 
the low-protein group. Thus the breakdown of liver protein during perfusion depended on the dietary state of the animals and amount of free amino acids in the medium.

Although lysine seems to be metabolized mainly in the liver(27), much lysine was formed and released from the liver. Liver protein contains much lysine (26), but this fact alone cannot explain the large amount of lysine released.

It is well known that alanine is released from the liver of fed rats (20), but taken up by the liver of rats that have been starved for 24 or $48 \mathrm{hr}(5,6,20)$. In this study, in which the animals were starved for $12 \mathrm{hr}$ before perfusion, release of alanine from the perfused liver far exceeded its decrease in the liver in all groups. The amount of alanine attributable to breakdown of liver protein was calculated as about $13.2 \mu \mathrm{mol}$, but $25.2 \mu \mathrm{mol}$ of alanine was released into the perfusion system. This suggests that about half the alanine released was newly formed in the liver and released into the medium, indicating that in the liver fasted for $12 \mathrm{hr}$, the rate of gluconeogenesis from alanine has still not been accelerated, unlike the case with a rat fasting for over $24 \mathrm{hr}$. As indicated by Felig (28), the movement of alanine is closely related to the energy level in the liver.

Previously, we reported (1) that the increase in total nonessential amino acids in the plasma and liver of rats on low-protein diets was mainly due to increase of serine. In this study, serine release from the liver was greater in the low-protein group than in the control group, in accordance with findings in vivo. However, decrease in free serine in the liver exceeded its release, suggesting that serine was degraded in the liver. Accordingly, the high level of serine in the liver of proteindeficient rats may be derived from other tissues besides the liver. Consistent with this possibility, Ishikawa's group (5-7) showed that the kidneys release much serine and we suggested previously (1) that muscle itself may also release serine.

This study showed that liver amino acid metabolism was affected by dietary protein and by the level of amino acids in the plasma. However, the results suggested that it may also be influenced by other organs, such as muscle, kidneys and gastrointestinal tissues, and further investigations are necessary on this problem.

The authors thank Mr. Y. Ogata for making the glass instruments for the perfusion apparatus used in this study. They also thank the Green Cross Corporation for supplying the FC-43 used as $\mathrm{O}_{2}-\mathrm{CO}_{2}$ carrier.

\section{REFERENCES}

1) Fujita, Y., Yamamoto, T., Rikimaru, T., Ebisawa, H., and Inoue, G. (1981): Effect of quality and quantity of dietary protein on free amino acids in plasma and tissues of adult rats. J. Nutr. Sci. Vitaminol., 27, 129-147.

2) Miller, L. L., Bly, C. G., Watson, M. L., and Bale, W. F. (1951): The dominant role of the liver in plasma protein synthesis. A direct study of the isolated perfused rat liver

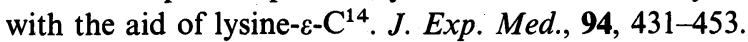

Vol. 27, No. 2, 1981 
3) Exton, J. H., and Park, C. R. (1967): Control of gluconeogenesis in liver. Am. J. Physiol., 242, 2622-2636.

4) Coulson, R. A., and Hernandez, T. (1967): Site of synthesis of amino acids in the intact cayman. Am. J. Physiol., 213, 411-417.

5) Aikawa, T., Matsutaka, H., Yamamoto, H., Okuda, T., Ishikawa, E., Kawano, T., and Matsumura, E. (1973): Gluconeogenesis and amino acid metabolism. II. Inter-organal relations and alanine in the amino acid metabolism of fasted rats. J. Biochem., 74, 1003-1017.

6) Matsutaka, H., Aikawa, T., Yamamoto, H., and Ishikawa, E. (1973): Gluconeogenesis and amino acid metabolism. III. Uptake of glutamine and output of alanine and ammonia by non-hepatic splanchnic organs of fasted rats and their metabolic significance. J. Biochem., 74, 1019-1029.

7) Yamamoto, H., Aikawa, T., Matsutaka, H., Okuda, T., and Ishikawa, E. (1974): Interorganal relationships of amino acid metabolism in fed rats. Am. J. Physiol., 226, 1428-1433.

8) McMenamy, R. H., Schoemaker, C., Richmond, J. E., and Elwyn, D. (1962): Uptake and metabolism of amino acids by the dog liver perfused in situ. Am. J. Physiol., 203, 407-414.

9) Mallette, L. E., Exton, J. H., and Park, C. R. (1969): Control of gluconeogenesis from amino acids in the perfused rat liver. J. Biol. Chem., 244, 5713-5723.

10) Parrilla, R., and Goodman, M. N. (1974): Nitrogen metabolism in the perfused rat liver. Nitrogen balance, redox state and rates of proteolysis. Biochem. J., 138, 341-348.

11) Topping, D. L., and Mayes, P. A. (1976): Comparative effects of fructose and glucose on the lipid and carbohydrate metabolism of perfused rat liver. Br. J. Nutr., 36, $113-125$.

12) Oyanagi, H., Sekita, M., Hironaka, T., Yamashita, S., Nogi, Y., Matsuda, T., Nakatani, M., Toshima, K., and Mitsuno, T. (1974): Fluorocarbon emulsion as the transporter of oxygen. I. Its physical properties and capacity of gas transport. Kokyu to Junkan (in Japanese), 22, 200-206.

13) Krone, W., Huttner, W. B., Kampf, S. C., Rittich, B., Seitz, H. J., and Tarnowski, W. (1974): Long-term perfusion of the isolated rat liver. Maintenance of its functional state by use of a fluorocarbon emulsion. Biochim. Biophys. Acta, 372, 55-71.

14) Hems, R., Ross, B. D., Berry, M. N., and Krebs, H. A. (1966): Gluconeogenesis in the perfused rat liver. Biochem. J., 101, 284-292.

15) Mortimore, G. E. (1961): Effect of insulin on potassium transfer in isolated rat liver. Am. J. Physiol., 200, 1315-1319.

16) Stein, W. H., and Moore, S. (1954): The free amino acids of human blood plasma. $J$. Biol. Chem., 211, 915-926.

17) Niiyama, Y., and Fujita, Y. (1972): Preparation of specimens for automatic amino acid analysis with special reference to removal of glutamine and asparagine. J. Jpn. Soc. Food Nutr. (in Japanese), 25, 353-355.

18) Chaney, A. L., and Marbach, E. P. (1963): A modified technique for ultramicro estimations of urea nitrogen. Clin. Chim. Acta, 8, 810-812.

19) Wannemacher, R. W., Jr., and Allison, J. B. (1968): Plasma amino acid concentrations in relation to protein synthesis, in Protein Nutrition and Amino Acid Pattern, ed. by Leathem, J. H., Rutgers Univ. Press, New Brunswick, New Jersey, pp. 206-227.

20) Hems, D. A., Davis, M. G., Thomas, A. J., and Whitton, P. D. (1976): Utilization of amino acids by the perfused rat liver. Nutr. Metab., 20, 404-414. 
21) Mondon, C. E., and Mortimore, G. E. (1967): Effects of insulin on amino acid release and urea formation in perfused rat liver. Am. J. Physiol., 212, 173-178.

22) Featherston, W. R., Rogers, Q. R., and Freedland, R. A. (1973): Relative importance of kidney and liver in synthesis of arginine by the rat. Am. J. Physiol., 224, 127-129.

23) Miller, L. L. (1962): in Amino Acid Pools, ed. by Holden, J. T., Elsevier, Amsterdam, p. 708 .

24) Ichihara, A., and Koyama, E. (1966): Transaminase of branched-chain amino acids. I. Branched chain amino acids- $\alpha$-ketoglutarate transaminase. J. Biochem., 59, 160-169.

25) Mimura, T., Yamada, C., and Swendseid, M. E. (1968): Influence of dietary protein levels and hydrocortisone administration on the branched-chain amino acid transaminase activity in rat tissues. J. Nutr., 95, 493-498.

26) Block, R. J., and Weiss, K. W. (1956): in Amino Acid Handbook, C. C. Thomas Co., Springfield, Ill., p. 344.

27) Noda, C., and Ichihara, A. (1976): Control of ketogenesis from amino acids. IV. Tissue specificity in oxidation of leucine, tyrosine, and lysine. J. Biochem., 80, 1159-1164.

28) Felig, P. (1973): The glucose-alanine cycle. Metabolism, 22, 179-207. 